\title{
RESEARCH
}

Open Access

\section{Dopamine transporter neuroimaging accurately assesses the maturation of dopamine neurons in a preclinical model of Parkinson's disease}

Julian L. Goggi ${ }^{1 \dagger}$, Lifeng Qiu ${ }^{2+}$, Mei Chih Liao ${ }^{3}$, Shivashankar Khanapur ${ }^{1}$, Lingfan Jiang ${ }^{1}$, Ramasamy Boominathan ${ }^{1}$, Siddesh V. Hartimath', Peter Cheng ${ }^{1}$, Fui Fong Yong ${ }^{1}$, Vanessa Soh'1, Xiaozhou Deng ${ }^{1}$, Youshan Melissa Lin ${ }^{3}$, Anna Haslop', Peng Wen Tan', Xiaoxia Zeng², Jolene W. L. Lee², Zhiwei Zhang ${ }^{2}$, Pragalath Sadasivam', Eng King Tan 4,5,6, Sajinder K. Luthra', William D. Shingleton ${ }^{7}$, Steve K. W. Oh ${ }^{3}$, Li Zeng ${ }^{2,6,8^{*}}$ and Edward G. Robins ${ }^{1,9^{*}}$ (D)

\begin{abstract}
Background: Significant developments in stem cell therapy for Parkinson's disease (PD) have already been achieved; however, methods for reliable assessment of dopamine neuron maturation in vivo are lacking. Establishing the efficacy of new cellular therapies using non-invasive methodologies will be critical for future regulatory approval and application. The current study examines the utility of neuroimaging to characterise the in vivo maturation, innervation and functional dopamine release of transplanted human embryonic stem cellderived midbrain dopaminergic neurons (hESC-mDAs) in a preclinical model of PD.
\end{abstract}

Methods: Female NIH RNu rats received a unilateral stereotaxic injection of 6-OHDA into the left medial forebrain bundle to create the PD lesion. hESC-mDA cell and sham transplantations were carried out 1 month post-lesion, with treated animals receiving approximately $4 \times 10^{5}$ cells per transplantation. Behavioural analysis, $\left.{ }^{18} \mathrm{~F}\right] \mathrm{FBCTT}$ and $\left[{ }^{18} \mathrm{~F}\right]$ fallypride microPET/CT, was conducted at 1,3 and 6 months post-transplantation and compared with histological characterisation at 6 months.

Results: PET imaging revealed transplant survival and maturation into functional dopaminergic neurons. $\left.{ }^{18} \mathrm{~F}\right] \mathrm{FBCTT}-$ PET/CT dopamine transporter (DAT) imaging demonstrated pre-synaptic restoration and $\left[{ }^{18} \mathrm{~F}\right]$ fallypride-PET/CT indicated functional dopamine release, whilst amphetamine-induced rotation showed significant behavioural recovery. Moreover, histology revealed that the grafted cells matured differently in vivo producing high- and lowtyrosine hydroxylase $(\mathrm{TH})$ expressing cohorts, and only $\left[{ }^{18} \mathrm{~F}\right] \mathrm{FBCTT}$ uptake was well correlated with differentiation.

(Continued on next page)

\footnotetext{
*Correspondence: Li_Zeng@nni.com.sg; Edward_Robins@sbic.a-star.edu.sg

${ }^{\dagger} J u$ lian L. Goggi and Lifeng Qiu contributed equally to this work.

${ }^{2}$ Neural Stem Cell Research Lab, Research Department, National

Neuroscience Institute, 11 Jalan Tan Tock Seng, Singapore 308433, Singapore

'Singapore Bioimaging Consortium, A*STAR, 11 Biopolis Way, \#01-02 HELIOS,

Singapore 138667, Singapore

Full list of author information is available at the end of the article
}

(c) The Author(s). 2020 Open Access This article is licensed under a Creative Commons Attribution 4.0 International License, which permits use, sharing, adaptation, distribution and reproduction in any medium or format, as long as you give appropriate credit to the original author(s) and the source, provide a link to the Creative Commons licence, and indicate if changes were made. The images or other third party material in this article are included in the article's Creative Commons licence, unless indicated otherwise in a credit line to the material. If material is not included in the article's Creative Commons licence and your intended use is not permitted by statutory regulation or exceeds the permitted use, you will need to obtain permission directly from the copyright holder. To view a copy of this licence, visit http://creativecommons.org/licenses/by/4.0/ The Creative Commons Public Domain Dedication waiver (http://creativecommons.org/publicdomain/zero/1.0/) applies to the data made available in this article, unless otherwise stated in a credit line to the data. 
(Continued from previous page)

Conclusions: This study provides further evidence for the value of in vivo functional imaging for the assessment of cell therapies and highlights the utility of DAT imaging for the determination of early post-transplant cell maturation and differentiation of hESC-mDAs.

Keywords: Parkinson's disease, Dopaminergic neuron, Cell therapy, PET imaging, DAT

\section{Background}

Parkinson's disease (PD) is a neurodegenerative disease characterised by the progressive loss of dopaminergic neurons projecting from the substantia nigra in the midbrain. This neuronal loss leads to the classical motor symptoms associated with PD including tremors, rigidity and akinesia [1]. Various types of dopamine replacement strategy have been investigated for the treatment of PD including medicinal, surgical and cell replacement strategies. Medicinal strategies are low cost and non-invasive, but long-term treatment is associated with side effects such as dyskinesia and patients eventually develop motor fluctuations [2]. Surgical strategies such as deep brain stimulation have been shown to significantly improve symptoms; however, this requires invasive surgery, with the associated risks of infection or haemorrhage, and has also been associated with long-term side effects including changes in cognition, apathy and anxiety [3]. Cell replacement therapies have been investigated for decades as an alternative treatment for PD and are based on the principle that transplanted dopaminergic neurons can functionally re-innervate the striatum. Early cell replacement studies used cells derived from human foetal ventral mesencephalon, and clinical follow-up studies showed successful re-innervation and functional dopamine release over 10 years after transplantation in some patients $[4,5]$. The use of human foetal tissue, however, is not a viable option due to ethical and logistical issues, so alternative, ethical and renewable cell sources are needed to be optimised for transplantation. Results from transplantation studies have shown that transplants with high levels of A9-like dopaminergic neurons are most likely to lead to long-term functional reinnervation [6-10], so the majority of studies have concentrated on midbrain dopaminergic neurons (mDAs) differentiated from human embryonic stem cells (hESCs) [11], induced pluripotent stem cells (iPSCs) and mesenchymal stem cells (MSCs) [12-14]. iPSCs and hESCderived mDAs have been shown to successfully restore function the denervated striatum in preclinical rat and primate models using standard neuroimaging, behavioural and histological measures [14, 15]. The success of such preclinical studies has led to the use of cell therapies for clinical trials; however, more rigorous preclinical studies are still needed to optimise graft maturation and therapeutic efficacy in vivo. Neuroimaging with PET allows the assessment of different aspects of dopamine neuron function longitudinally in vivo. Examples include $\left[{ }^{18} \mathrm{~F}\right]$ FDOPA which measures the biosynthesis of dopamine, $\left[{ }^{11} \mathrm{C}\right]$ raclopride and $\left[{ }^{18} \mathrm{~F}\right]$ fallypride which are capable of assessing dopamine release and tropane-derived ligands such as $\left[{ }^{18} \mathrm{~F}\right] \mathrm{FP}-\beta$-CIT, $\left[{ }^{18} \mathrm{~F}\right]$ FE-PE2I and $\left[{ }^{18} \mathrm{~F}\right]$ FBCTT that have been developed as clinical and preclinical PET radiopharmaceuticals for the quantification of presynaptic dopamine transporter (DAT) expression [16-19].

Neuroimaging is also able to assess the safety of cell transplants by measuring potential tumourigenicity associated with transplanted cells using radiopharmaceuticals such as $\left[{ }^{18} \mathrm{~F}\right] \mathrm{FDG}$ for metabolism and $\left[{ }^{18} \mathrm{~F}\right] \mathrm{FLT}$ for proliferation [20]. Such non-invasive imaging measures will be critical for the assessment of mDA cell therapies in clinical trials. In the current study, we have assessed the in vivo maturation, innervation and functional dopamine release of aggregates of immature mDA neurons [21] using neuroimaging and behavioural analysis for 6 months post-transplantation, correlating these measures to graft maturation.

\section{Materials and methods}

\section{Preparation of hESCs and mDA neuron differentiation}

The hESC line HES-3 was obtained from ES Cell International Pte Ltd., Singapore [15]. HES-3 cells were expanded and maintained in $\mathrm{mTeSR}^{\mathrm{im}}$ (STEMCELL Technologies, Canada) medium on tissue culture plates coated with Geltrex (Thermo Fisher Scientific, USA). The cells were passaged at 40 to $50 \%$ confluency using ReLeSR $^{\text {mi }}$ (STEMCELL Technologies, Canada), in accordance with the manufacturer's instructions.

The DA neuron differentiation method was derived from a floor plate (FP)-based protocol and modified from Kirkeby et al. [22]. Cells were dissociated with ACCUTASE $^{\mathrm{m}}$ (STEMCELL Technologies, Canada) and cultured on laminin-111-coated $(10 \mu \mathrm{g} / \mathrm{ml}$; BioLamina, Sweden) tissue culture plate in a DIM medium consisting of DMEM/F12:Neurobasal medium (1:1), N2 supplement (1:100), B27 supplement without vitamin A (1:50), penicillin/streptomycin (1:100), GlutaMAX (1:100), nonessential amino acids (1:100) and $100 \mu \mathrm{M}$ 2mercaptoethanol (Life Technologies, USA), in the presence of $10 \mu \mathrm{M}$ Y27632 (Rock inhibitor; Selleckchem, USA), $10 \mu \mathrm{M}$ SB431542 (SB; Selleckchem, USA), $0.1 \mu \mathrm{M}$ LDN193189 (LDN; Selleckchem, USA), $200 \mathrm{ng} / \mathrm{ml}$ ShhC24II (Shh) (R\&D Systems, USA) and $0.8 \mu \mathrm{M}$ 
ChIR99021 (ChIR; Selleckchem, USA) for the first 2 days of differentiation. On day 2, the cells were maintained in DIM medium supplemented with SB, LDN, Shh, ChIR and $2 \mu \mathrm{M}$ Purmorphamine (Pur; Selleckchem, USA) with a medium change every 2 days. On day 8 , the cells were differentiated in DIM medium supplemented with Shh, ChIR and $100 \mathrm{ng} / \mathrm{ml}$ FGF8 (R\&D Systems, USA) with daily medium change. On day 12 of differentiation, the cells were dissociated with ACCUTASE ${ }^{\mathrm{im}}$ and cultured as neurospheres $(1 \times 104$ cells per neurosphere) using AggreWell ${ }^{\text {m" }} 800$ (STEMCELL Technologies, Canada) in DDM medium consisting of Neurobasal medium, B27 supplement without vitamin A (1:50), penicillin/streptomycin (1:100), GlutaMAX (1:100) and $100 \mu \mathrm{M} 2$ mercaptoethanol (Life Technologies, USA), in the presence of Rock inhibitor, FGF8, $10 \mathrm{ng} / \mathrm{ml}$ BDNF (STEMCE LL Technologies, Canada) and $2 \mathrm{mM}$ ascorbic acid (ASC; Sigma-Aldrich, USA). On day 14, the cells were differentiated in DDM medium supplemented with FGF8, BDNF, ASC, $10 \mathrm{ng} / \mathrm{ml} \mathrm{GDNF}$ (STEMCELL Technologies, Canada), 1 ng/ml TGF $\beta 3$ (STEMCELL Technologies, Canada) and $5 \mu \mathrm{M}$ DAPT (Selleckchem, USA). On day 16, the neurospheres were embedded in Mebiol $^{\circ}$ Gel (Cosmo Bio Co. Ltd., Japan) and cultured in DDM medium supplemented with BDNF, ASC, GDNF, TGF 33 , DAPT and CultureOne ${ }^{\mathrm{Tm}}$ Supplement (1:100; Thermo Fisher Scientific, USA) with medium change every 2 to 3 days. On day 23 of differentiation, the neurospheres were dissociated with ACCUTASE ${ }^{\mathrm{m}}$ to reform smaller-sized neurospheres $(5 \times 103$ cells per neurosphere) using AggreWell ${ }^{\mathrm{m}} 800$. On day 25 , approximately $4 \times 105$ cells or 80 neurospheres were delivered per transplantation. Neurospheres not used for transplantation were embedded in $\mathrm{Mebiol}^{\circ} \mathrm{Gel}$ and further differentiated in Brainphys ${ }^{\mathrm{Tn}}$ Neuronal Medium (STEMCELL Technologies, Canada) containing BDNF, ASC, GDNF, TGF 33, DAPT, CultureOne ${ }^{\mathrm{m}}$ Supplement and NeuroCult $^{\text {mix }}$ SM1 Neuronal Supplement (1:50, STEMCELL Technologies, Canada) with medium changed every 3 to 4 days until day 40 of differentiation [23].

\section{Generation of neurospheres for transplantation}

On day 23 of differentiation, the neurospheres were dissociated with ACCUTASE ${ }^{\text {ta }}$ to reform smaller-sized neurospheres (5000 cells per neurosphere) for transplantation at day 25 . On day 25 , approximately $4 \times$ $10^{5}$ cells or 80 neurospheres were delivered per transplantation.

\section{Immunofluorescence}

Cell aggregates were fixed with $4 \%$ paraformaldehyde (Affymetrix, USA) at room temperature (rtp) for $1 \mathrm{~h}$, cryoprotected in 30\% sucrose and sectioned by a cryostat before being mounted on glass slides. Sections were permeabilized with $0.5 \%$ Triton (Sigma-Aldrich, USA) at rtp for $10 \mathrm{~min}$. They were then blocked with blocking solution consisting of 3\% donkey serum (Sigma-Aldrich, USA), 2\% CellMaxx ${ }^{\text {tim }}$ BSA (MP Biomedicals, USA), 0.1\% Triton (Sigma-Aldrich, USA) in PBS for at least $1 \mathrm{~h}$ before incubating with primary antibodies (1:500 rabbit anti-TH (Pel-Freez, USA) and 1: 1000 mouse anti-Tuj1 (Covance, USA); all diluted in blocking solution) overnight at $4{ }^{\circ} \mathrm{C}$. Cells were incubated with secondary antibodies (1:500 donkey anti-rabbit 488 and 1:500 donkey anti-mouse 555; all diluted in blocking solution) at rtp for $1 \mathrm{~h}$ before staining with DAPI solution (all Life Technologies, USA) at rtp for $5 \mathrm{~min}$. Coverslips were mounted with VECTASHIELD Antifade Mounting Medium (Vector Laboratories Inc., USA).

\section{Western blot and HPLC analysis}

At various time points including day 50 of differentiation for HPLC analysis, the neurospheres were dissociated with ACCUTASE ${ }^{\mathrm{mm}}$ into single cells. $1 \times 106$ cells per vial would be snap frozen in liquid $\mathrm{N}_{2}$ after washing with PBS. Western blot was carried out using $30 \mu \mathrm{g}$ of total proteins per sample with primary antibodies (1:1000 rat anti-DAT (Millipore, USA), 1:1000 rabbit anti-TH (PelFreez, USA) and 1:10,000 rabbit anti-GAPDH (Cell Signaling, USA)). HPLC analysis was performed as described previously [15].

\section{6-Hydroxydopamine lesioning}

A total of 75 young female $\mathrm{NIH} \mathrm{RNu}$ rats were purchased from InVivos Pte Ltd., Singapore, housed 4 to a cage with free access to food and water and held under a 12:12-h light-dark cycle. All surgical operations were performed under ketamine xylazine anaesthesia. Animals received unilateral stereotaxic injections of 6-OHDA. $\mathrm{Br}$ $(5 \mu \mathrm{g} / \mu \mathrm{l} 4 \mu \mathrm{l}$ in $0.9 \% \mathrm{NaCl}$ containing $0.2 \mathrm{mg} / \mathrm{ml}$ ascorbic acid) injected into the left medial forebrain bundle (MFB) using a 5- $\mu$ l Hamilton syringe $(-4.4 \mathrm{~mm}$ AP, 1.2 $\mathrm{mm} \mathrm{ML}$ and $8.6 \mathrm{DV}$ relative to the bregma; $7105 \mathrm{KH}$ $5.0 \mu \mathrm{l}$, Hamilton Company, Bonaduz, Switzerland, https://www.hamiltoncompany.com/). The injection rate was $0.5 \mu \mathrm{l} / \mathrm{min}$, and the cannula was left in place for additional $5 \mathrm{~min}$ before slowly retracting it.

\section{Cell transplantation}

Cell transplantations were conducted 1 month after 6OHDA lesion to allow for complete lesion formation. The rats were anaesthetized with a mixture of ketamine and xylazine as described above and then positioned in a stereotactic injection apparatus. Suspensions of concentrated cell aggregates $\left(4 \times 10^{5}\right.$ cells in $\left.4 \mu \mathrm{l}\right)$ were loaded into a Hamilton syringe and injected into the left striatum (AP, $+0.8 \mathrm{~mm}$; ML, $2.5 \mathrm{~mm}$; DV, $5 \mathrm{~mm}$ ). The needle was left in place for $5 \mathrm{~min}$ after the injection. 


\section{Radiochemistry}

All radiochemical reactions were carried out in anhydrous solvents in closed clear V-vials under air unless stated otherwise. All commercially available reagents were used without further purification unless stated otherwise. $\left[{ }^{18} \mathrm{~F}\right]$ fluoride was produced via the ${ }^{18} \mathrm{O}(p$, $n)^{18} \mathrm{~F}$ reaction using a GE PETrace 800 series cyclotron at the Clinical Imaging Research Center (CIRC) and delivered as $\left[{ }^{18} \mathrm{~F}\right]$ fluoride in enriched $\left[{ }^{18} \mathrm{O}\right]$ water. Acetonitrile, ethanol, potassium carbonate and Kryptofix 222 were of analytical grade and bought from Sigma-Aldrich. Water was obtained from an ELGA water purification system (model PF3XXXXM1). Tosyl-Fallypride TFA salt was bought from Bioduro LLC. MBCTT was bought from ABX. V-vials were bought from Fisher Scientific. Accell $^{\text {tw }}$ Plus QMA carbonate $(46 \mathrm{mg})$ cartridges, Oasis ${ }^{\circ}$ HLB light $(30 \mathrm{mg})$ cartridges and ${ }^{\mathrm{t}} \mathrm{C} 18$ light cartridges were bought from Waters. Gibco ${ }^{\text {ma }}$ phosphate-buffered saline (PBS) solution $1 \times \mathrm{pH} 7.4$ was bought from Fisher Scientific. Detailed accounts for the radiosynthesis of $\left[{ }^{18} \mathrm{~F}\right] \mathrm{FBCTT},\left[{ }^{18} \mathrm{~F}\right]$ fallypride and $\left[{ }^{18} \mathrm{~F}\right]$ fluoro-L-thymidine can be found in the Supplementary Materials.

\section{Radiosynthesis of $\left[{ }^{18} \mathrm{~F}\right] \mathrm{FBCTT}$}

$\left[{ }^{18} \mathrm{~F}\right]$ FBCTT was prepared by nucleophilic substitution of the MBCTT mesylate precursor with $\left[{ }^{18} \mathrm{~F}\right]$ fluoride. $\left[{ }^{18} \mathrm{~F}\right] \mathrm{FBCTT}$ was formulated for injection in $10 \%$ ethanol in phosphate-buffered saline as a colourless solution, $\mathrm{pH}$ of 7.4 in a total reaction and purification time of $90 \mathrm{~min}$ and with a radiochemical yield of 19-27\% (non-decaycorrected, $n=10$ ), radiochemical purity $>99 \%$ and molar activity of $60-1927 \mathrm{GBq} / \mu \mathrm{mol}$.

\section{Radiosynthesis of $\left[{ }^{18} \mathrm{~F}\right]$ fallypride}

$\left[{ }^{18} \mathrm{~F}\right]$ fallypride was prepared by nucleophilic substitution of the tosyl-Fallypride - TFA salt precursor with $\left[{ }^{18} \mathrm{~F}\right]$ fluoride. $\left[{ }^{18} \mathrm{~F}\right]$ fallypride was formulated for injection in $10 \%$ ethanol in phosphate-buffered saline as a colourless solution, $\mathrm{pH}$ of 7.4 in a total reaction time of $90 \mathrm{~min}$ in a radiochemical yield of $5-19 \%$ (non-decaycorrected, $n=10$ ), radiochemical purity $>99 \%$ and a molar activity of $67-634 \mathrm{GBq} / \mu \mathrm{mol}$.

\section{Radiosynthesis of $\left[{ }^{18} \mathrm{~F}\right] \mathrm{FLT}$}

$\left[{ }^{18} \mathrm{~F}\right]$ fluoro-L-thymidine $\left(\left[{ }^{18} \mathrm{~F}\right] \mathrm{FLT}\right)$ was synthesised using the Scintomics GRP $^{\text {min }}$ automated synthesis module (SCINTOMICS GmbH, Fürstenfeldbruck, Germany) equipped with a ready-to-use disposable single-use reagent cassette. $\left[{ }^{18} \mathrm{~F}\right] \mathrm{FLT}$ synthesis was complete in approximately $60 \mathrm{~min}$ providing $\left[{ }^{18} \mathrm{~F}\right] \mathrm{FLT}$ in $16 \%$ nondecay corrected radioactivity yield, in a total volume of $11 \mathrm{ml}$ with a radioactive concentration of $73 \mathrm{MBq} / \mathrm{ml}$ at pH 6.0-6.5 with a radiochemical purity of $>99 \%$ with a molar activity of $532 \mathrm{GBq} / \mu \mathrm{mol}$.

\section{PET imaging}

Imaging assessment of lesion success was performed pre-transplantation 4 weeks after 6-OHDA lesion. Animals that displayed greater than $90 \%$ lesion were selected for cell transplantation. Imaging was repeated at 1 month, 3 months and 6 months post-transplantation.

$\mathrm{NIH} \mathrm{RNu}$ rats ( $n=8$ per imaging group) were injected with a solution of either $\left[{ }^{18} \mathrm{~F}\right]$ FBCTT $(\sim 20 \mathrm{MBq}$ in 0.5 $\mathrm{ml})$, $\left[{ }^{18} \mathrm{~F}\right]$ fallypride $(\sim 20 \mathrm{MBq}$ in $0.5 \mathrm{ml})$ or $\left[{ }^{18} \mathrm{~F}\right] \mathrm{FLT}(\sim$ $5 \mathrm{MBq}$ in $0.5 \mathrm{ml})$, via the lateral tail vein, and static images were acquired at either $60-90 \mathrm{~min}, 90-120 \mathrm{~min}$ or 30-50 min, respectively, post-injection (static image duration and timings were based on previous dynamic studies to determine the optimal imaging conditions prior to the initiation of the study). The PET and CT images were co-registered to an MRI brain atlas to confirm the anatomical location of the radiopharmaceutical uptake. Uptake of radioactivity was determined by the placement of a region of interest (ROI) over the striatal regions, and the cerebellum uptake was used as a reference region where appropriate. The tissue concentrations are presented as percent injected dose/gram (\%ID/g).

\section{Behavioural analysis}

The methamphetamine-induced rotation assay was performed pre-transplantation 4 weeks after 6-OHDA lesion. A dose of $5 \mathrm{mg} / \mathrm{kg}$ of methamphetamine was injected intraperitoneally (i.p.), and the rotation behaviour was recorded for $40 \mathrm{~min}$. Animals that displayed greater than 5 ipsilateral rotations/minute were selected for cell transplantation. Behavioural rotation tests were repeated at 1 month, 3 months and 6 months posttransplantation.

\section{Immunocytochemistry and immunohistochemistry staining}

For immunocytochemistry staining, cell aggregates were fixed in 4\% PFA (Sigma-Aldrich, Singapore), cryoprotected in $30 \%$ sucrose solution, cut on a cryostat and mounted on glass slides. For IHC, the rats were transcardially perfused with $4 \%$ PFA; the brains were then removed, post-fixed overnight in $4 \%$ PFA and cryoprotected in $30 \%$ sucrose. The brain sections were cut with a cryostat and mounted on glass slides. For immunofluorescence, blocking and antibody incubations were performed with a solution of $1 \%$ BSA and $0.1 \%$ Triton X-100 (Sigma-Aldrich, Singapore) in PBS. The samples were blocked for $1 \mathrm{~h}$ at $\mathrm{RT}$, incubated overnight in primary antibody solutions at $4{ }^{\circ} \mathrm{C}$ and incubated for $2 \mathrm{~h}$ in secondary antibody solutions at RT. After the primary and secondary antibody incubations, the sections were washed four times in PBS. The primary antibodies used are listed in supplemental Table S1. Alexa Fluor 488/568 goat anti-rabbit/mouse IgG (1:400, Invitrogen, 
Singapore, https://www.thermofisher.com) was used as secondary antibodies for fluorescence labelling. A peroxidase-conjugated goat anti-mouse secondary antibody (Vector Laboratories, Burlingame, CA, USA, https:/vectorlabs.com) was used for 3,30-diaminobenzidine (DAB) (Vector Laboratories) labelling, and positive reactions were detected by the avidin-biotin complex $(\mathrm{ABC})$ method (Vector Laboratories). The slices were mounted with fluorescence mounting medium (Dako, Carpinteria, CA, USA, www.dako.com) or DPX (for IHC-DAB staining), and images were obtained with a confocal microscope (LSM710, Olympus, Tokyo, Japan, www.olympus.com).

\section{Stereological quantification of grafted mDA cells}

The total numbers of grafted mDA cells that were immunoreactive for the human nucleus antigen (hNUC), neuronal nuclei antigen (NEUN), TH and FOXA2 were estimated using stereological, unbiased and systematic sampling method described before [24, 25]. Briefly, frozen coronal sections ( $16 \mu \mathrm{m}$ thick) were cut and serially collected. Stereological quantification was carried out with every 15th section to cover the entire graft from the rostral focal plane in which the grafted cells started to emerge to the caudal plane where the grafted cells disappeared. The optical images were obtained by an Olympus microscope using a $\times 40$ oil immersion objective. At least eight sections were counted for each graft. The total numbers in the grafts were calculated according to the optical fractionator equation.

\section{Statistical analysis}

Statistical analyses were carried out by using the GraphPad Prism Software (San Diego, CA) and performed using a 2-way ANOVA with post hoc Bonferroni test where appropriate. All data are presented as the mean and standard deviation (mean \pm SD) unless otherwise stated.

\section{Results}

\section{In vitro characterisation of hESC-derived midbrain} dopaminergic ( $\mathrm{mDA})$ neurons

We previously published a systematic study that compared the engraftment efficiency, long-term survival, differentiation, maturation and functional recovery of three groups of human embryonic stem cell (hESC)-derived midbrain dopaminergic (mDA) progenitors and neurons at distinct differentiation stages in a murine model of PD [15]. The three distinct groups of differentiated cells were $\mathrm{FOXA}_{2}{ }^{+} / \mathrm{LMX} \mathrm{A}^{+} \mathrm{mDA}$ progenitors, immature $\mathrm{TH}^{+} / \mathrm{NURR}^{+} \mathrm{mDA}$ neurons and more mature mDA neurons with extended neurite outgrowth. We found that transplantation of immature mDA neuronal aggregates was the most efficient in terms of post- transplantation survival ability, neuronal differentiation and maturation in vivo. Therefore, the aggregates of immature mDA neurons derived from hESC were utilised in the current study (Fig. 1a).

The batches of ESC-derived immature mDA neurons were characterised by immunostaining and western blot for standard dopaminergic markers including tyrosine hydroxylase $(\mathrm{TH})$ and dopamine transporter (DAT) as well as HPLC analysis for the production of dopamine and its metabolite 3,4-dihydroxyphenylacetic acid (DOPAC) (Fig. 1b-d). Our results are in agreement with our prior work clearly demonstrating the presence of $\mathrm{TUJ}^{+} / \mathrm{TH}^{+}$immature mDA neurons (Fig. 1b). Western blot data showed an increase in the production of $\mathrm{TH}$ and DAT over time demonstrating an increase in differentiation efficiency towards the $\mathrm{mDA}$ lineage (Fig. 1c), and HPLC analysis confirmed that the hESC-derived immature mDA neurons can successfully mature and produce dopamine $\left(n=3,2.33 \pm 0.4 \mathrm{pM} / 10^{6}\right.$ cells $)$ and DOPAC $\left(n=3,1.49 \pm 0.2 \mathrm{pM} / 10^{6}\right.$ cells $)$ by day 35 of differentiation (Fig. 1d).

\section{Quantification of striatal re-innervation by imaging with $\left[{ }^{18} \mathrm{~F}\right] \mathrm{FBCTT}$}

Figure $2 \mathrm{a}$ shows the representative images of $\left[{ }^{18} \mathrm{~F}\right] \mathrm{FBCTT}$ uptake in the striata of implanted and vehicle-treated animals at the time points studied. Figure $2 \mathrm{~b}$ shows the quantification of $\left[{ }^{18} \mathrm{~F}\right] \mathrm{FBCTT}$ uptake as a measure of DAT expression in the transplanted and vehicle-treated lesioned rat striata ( $n=8$ rats per group). Imaging assessment of lesion success was performed pre-transplantation, 4 weeks after 6-OHDA lesioning with $\left[{ }^{18} \mathrm{~F}\right] \mathrm{FBCTT}$ to quantify DAT expression and clearly demonstrated a reduction of greater than $95 \%(4.3 \% \pm 1.9)$ compared to the contralateral intact side. One month post-implantation of mDAs, no significant increase in $\left.{ }^{18} \mathrm{~F}\right] \mathrm{FBCTT}$ was observed in the transplanted striatum $(4.9 \% \pm 2.5)$ compared to the vehicle-treated $(5.0 \% \pm 2.3)$. Small increases in $\left[{ }^{18} \mathrm{~F}\right] \mathrm{FBCTT}$ retention were observed in both the transplanted striatum $(9.3 \% \pm 2.3)$ and the vehicle-treated striatum $(12.3 \% \pm 5.3)$ at 3 months postimplantation indicating a measure of spontaneous recovery independent of $\mathrm{mDA}$ implantation. By 6 months postimplantation, however, a significant and persistent increase in $\left[{ }^{18} \mathrm{~F}\right] \mathrm{FBCTT}$ retention was observed in the transplanted striatum $(29.2 \% \pm 13.4)$ compared to the vehicle-treated lesioned striatum $(9.7 \% \pm 6.9)$ indicating successful maturation of the implanted mDAs into DAT-expressing mature dopaminergic neurons $\left({ }^{* *} P<0.01\right.$, data shown as mean \pm SD \% change in $\left[{ }^{18} \mathrm{~F}\right] \mathrm{FBCTT}$ uptake using the intra-animal contralateral intact striatum uptake as reference).

Figure 2c shows the longitudinal quantification of $\left[{ }^{18} \mathrm{~F}\right] \mathrm{FBCTT}$ uptake in the low-TH and high-TH transplanted lesioned striata ( $n=4$ per group) compared to vehicle. One month post-successful stereotactic 


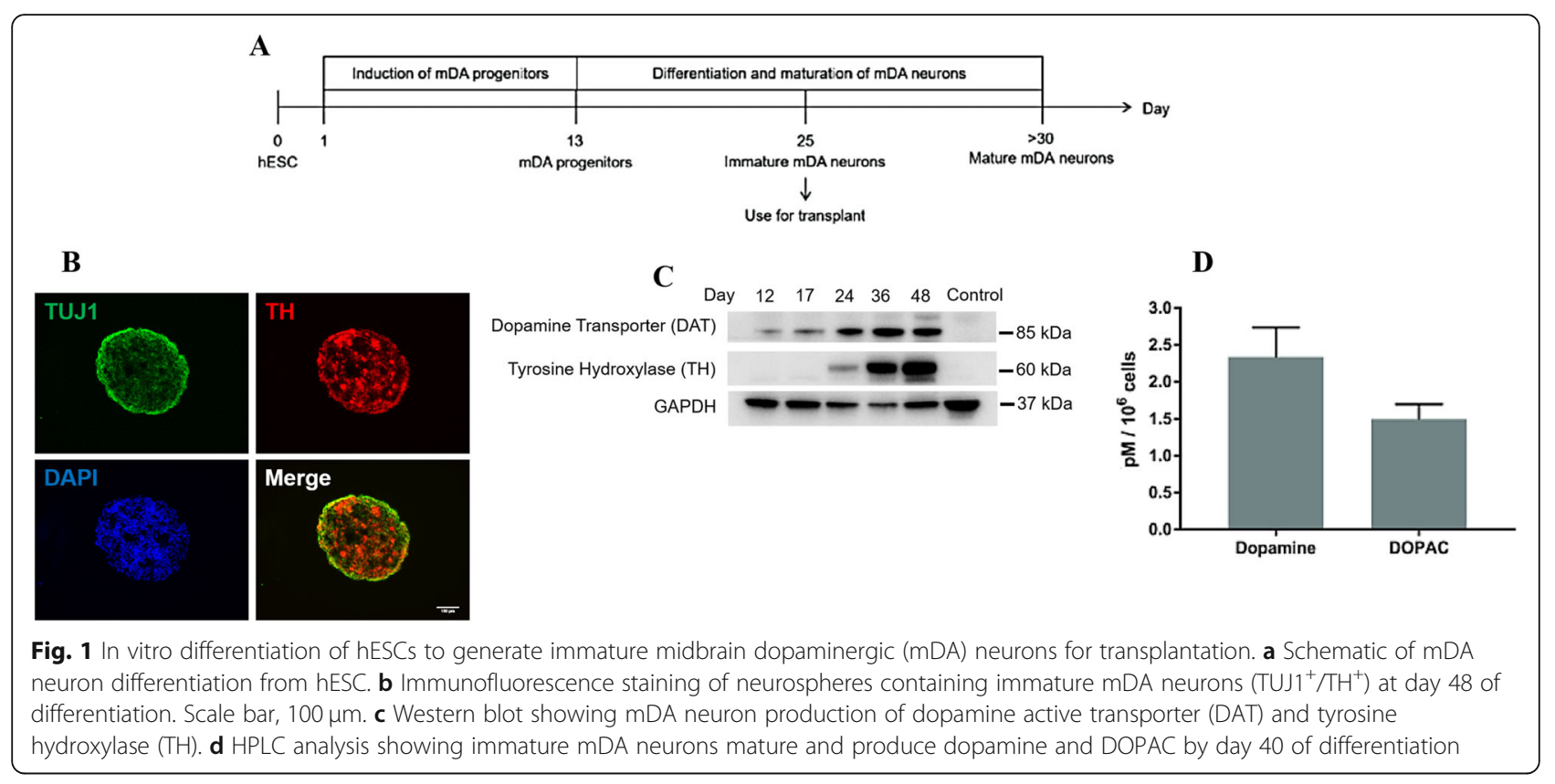

implantation of mDAs, no significant increase in $\left[{ }^{18} \mathrm{~F}\right] \mathrm{FBCTT}$ was observed in the low-TH transplanted striatum $(3.8 \% \pm 0.4)$ or high-TH transplanted striatum $(5.6 \% \pm 4.6)$ compared to vehicle $(5.0 \% \pm 2.3)$. Small increases in $\left[{ }^{18} \mathrm{~F}\right] \mathrm{FBCTT}$ retention were observed in the low-TH transplanted striatum $(8.1 \% \pm 1.2)$ and high- $\mathrm{TH}$ transplanted striatum $(10.7 \% \pm 2.9)$ but were not significantly different from the vehicle-treated striatum $(12.3 \% \pm$ 5.3) at 3 months post-implantation indicating a measure of spontaneous recovery independent of $\mathrm{mDA}$ implantation. By 6 months post-implantation, however, a significant and persistent increase in $\left[{ }^{18} \mathrm{~F}\right] \mathrm{FBCTT}$ retention was observed in the low- $\mathrm{TH}$ transplanted striatum $(19.4 \% \pm$ 4.7, $\left.{ }^{*} P<0.05\right)$ and the high-TH transplanted striatum $(43.3 \% \pm 9.8, * * 00.01)$ compared to the vehicle-treated lesioned striatum $(9.7 \% \pm 6.9)$ indicating successful maturation of the implanted mDAs into DAT-expressing dopamine cells (data shown as mean $\pm \mathrm{SD} \%$ change in $\left[{ }^{18} \mathrm{~F}\right] \mathrm{FBCTT}$ uptake using the intra-animal contralateral intact striatum uptake as reference).

\section{Quantification of dopamine release by imaging with $\left[{ }^{18} \mathrm{~F}\right]$ fallypride}

Figure 3a shows the representative images of $\left[{ }^{18} \mathrm{~F}\right]$ fallypride uptake in the striata of implanted and vehicle-treated animals at the time points studied. Figure $3 \mathrm{~b}$ shows the longitudinal assessment of $\left[{ }^{18} \mathrm{~F}\right]$ fallypride uptake as a measure of post-synaptic $D_{2} / D_{3}$ receptor occupancy ( $n=8$ rats per group). Pre-transplant imaging with $\left[{ }^{18} \mathrm{~F}\right]$ fallypride showed a significant increase in binding in the lesioned side compared to the contralateral intact side $(118.3 \% \pm 8.1)$ consistent with a profound reduction in dopamine release from the lesioned side. One month post-successful stereotactic implantation of mDAs, no significant change in dopamine receptor occupancy was observed in the transplanted striatum $(118.9 \% \pm 9.3)$ compared to vehicle $(113.5 \% \pm 10.7)$. Six months after implantation, the $\mathrm{D}_{2} / \mathrm{D}_{3}$ receptor occupancy was normalised back to intact levels in the transplanted striatum $(97.5 \% \pm 7.2)$ compared to the vehicletreated striatum $(111.7 \% \pm 11.9)$ demonstrating functional dopamine release from the transplanted dopamine cells $\left({ }^{*} P<0.05\right.$, data shown as mean \pm SD \% change in $\left[{ }^{18} \mathrm{~F}\right]$ fallypride uptake using the intra-animal contralateral intact striatum uptake as reference).

Figure $3 \mathrm{c}$ shows the longitudinal quantification of $\left[{ }^{18} \mathrm{~F}\right]$ fallypride uptake in the low-TH and high-TH transplanted lesioned striata ( $n=4$ per group) compared to vehicle. One month post-successful stereotactic implantation of mDAs, no significant dopamine occupancy was observed in either the low- $\mathrm{TH}$ transplanted striatum $(123.2 \% \pm 7.9)$ or the high- $\mathrm{TH}$ transplanted striatum $(115.4 \% \pm 9.7)$ compared to vehicle $(113.5 \% \pm 10.7)$. Six months after implantation, the $\mathrm{D}_{2} / \mathrm{D}_{3}$ receptor occupancy was normalised back to intact levels in both the low-TH transplanted striatum $(95.5 \% \pm 3.1)$ and the high$\mathrm{TH}$ transplanted striatum $(99.1 \% \pm 8.3)$ compared to the vehicle-treated striatum $(111.7 \% \pm 11.9)$ demonstrating functional dopamine release from both sets of transplanted dopamine cells ( ${ }^{*} P<0.05$, data shown as mean \pm $\mathrm{SD} \%$ change in $\left[{ }^{18} \mathrm{~F}\right]$ fallypride uptake using the intraanimal contralateral intact striatum uptake as reference).

\section{Assessment of graft proliferation by imaging with $\left[{ }^{18} \mathrm{~F}\right] \mathrm{FLT}$}

To quantify the proliferation in the transplanted tissue grafts at the 6-month time point, the transplanted animals were imaged with $\left[{ }^{18} \mathrm{~F}\right] \mathrm{FLT}$. No significant 


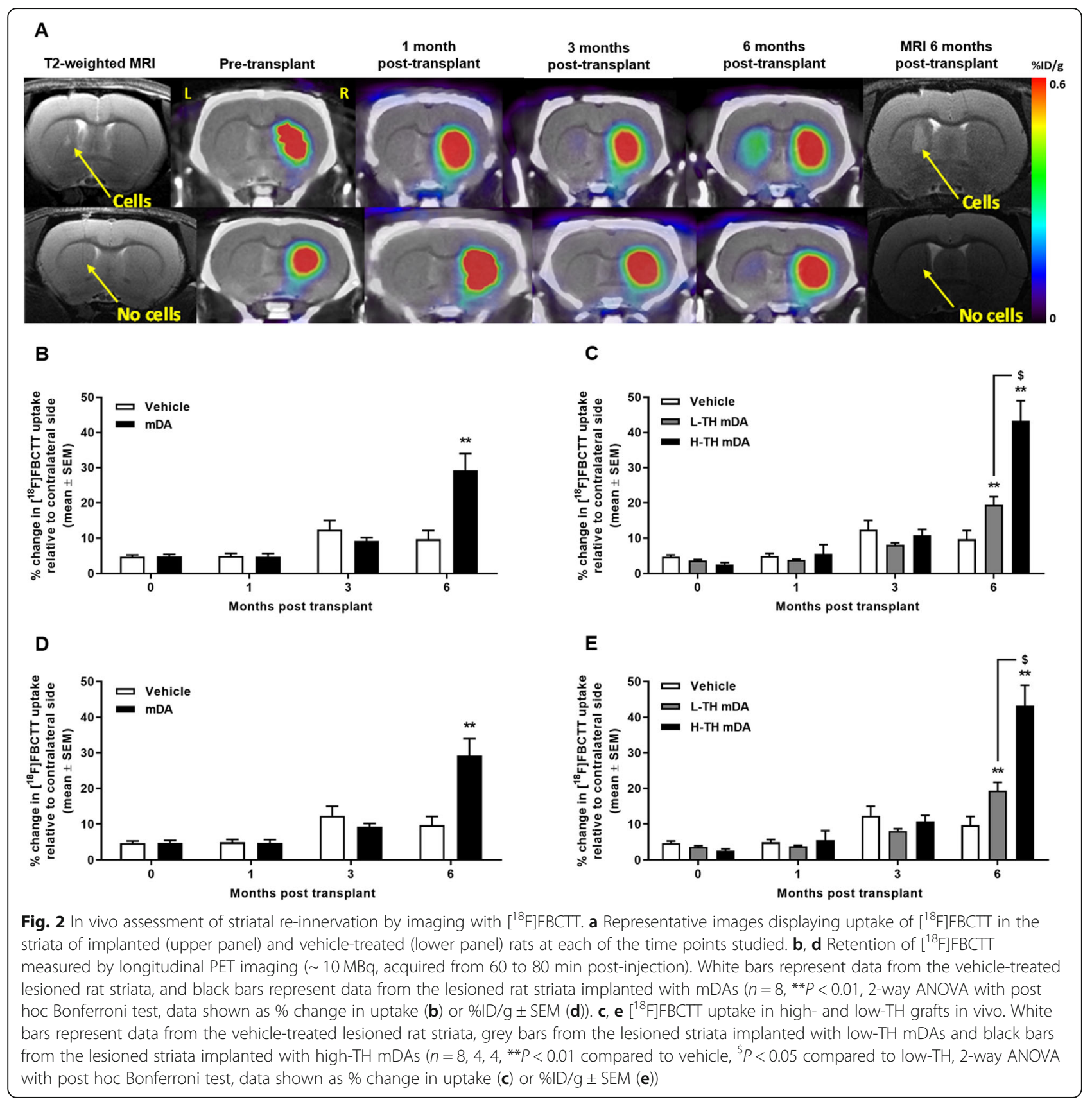

difference in $\left[{ }^{18} \mathrm{~F}\right] \mathrm{FLT}$ uptake was observed between the transplant region and the contralateral intact nonlesioned striatum for either graft.

Graft survival, neuronal maturation and mDA neuronal differentiation of the transplanted cells at 6 months posttransplantation

Immunohistochemistry (IHC) was performed to evaluate the survival, neuronal maturation and $\mathrm{mDA}$ differentiation of the transplanted cells. The transplanted cells showed substantial survival, as indicated by hNuc staining (Fig. 4A). No sign of overgrowth or necrosis was observed. The majority of surviving grafted cells matured into neurons (as shown by NeuN expression) whilst a portion of these grafted cells differentiated into $\mathrm{mDA}$ progenitors (as indicated by FoxA2 expression) and DA neurons (TH expression, Fig. 4A).

We found the percentages of $\mathrm{TH}^{+}$cells in the surviving grafts varied amongst animals. We grouped the grafts into either high-TH grafts $(13.33 \pm 2.06 \%)$ or lowTH grafts $(6.65 \pm 1.29 \%$; " $P<0.05)$ (Fig. $4 \mathrm{~B}, \mathrm{C})$.

Stereological counting of $\mathrm{hNuc}^{+}$cells showed no significant difference in cell survival between the high-TH and low-TH grafts (Fig. 4C (a)) nor any difference in the 


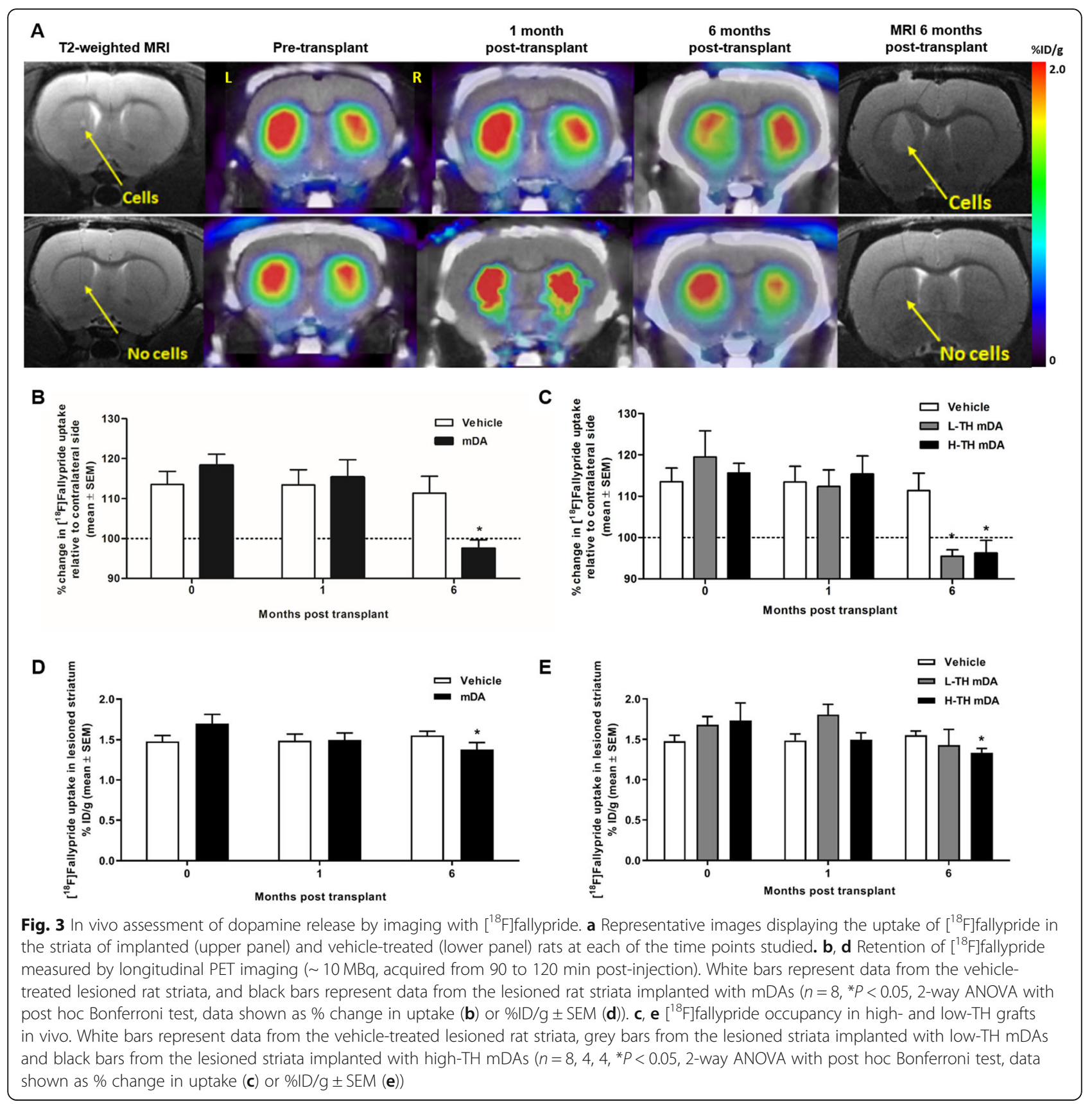

percentage of NeuN-positive cells between the high-TH grafts $(69.88 \pm 14.19 \%)$ and the low-TH grafts $(70.33 \pm$ $4.92 \%)$, indicating that the pan-neuronal differentiation was the same (Fig. 4B (a-f); Fig. 4C (b)). Furthermore, no significant difference in the percentage of $\mathrm{mDA}$ progenitors (FOXA2-positive cells) was found between high-TH graft $(25.08 \pm 6.87 \%)$ and low-TH graft $(23.46 \pm 7.39 \%)$ (Fig. 4B (g-l); Fig. 4C (b)). These data indicated that the transplanted cells differentiated into neurons, midbrain progenitors and DA neurons with decreased proportions.
Grafted DA neurons are of midbrain A9 DA neuronal fate More markers were evaluated to confirm the midbrain dopaminergic neuron identity of the $\mathrm{TH}^{+}$cells within the grafts. In both high- $\mathrm{TH}$ and low- $\mathrm{TH}$ grafts, all $\mathrm{TH}^{+}$ cells are positive for midbrain neuronal markers EN1, Lmx1a and FOXA2 (Fig. 5a). Furthermore, most of the mature $\mathrm{TH}^{+}$neurons were also positive for A9 neuronal marker, Girk2 (Fig. 5a). Dense hNCAM staining signal revealed the innervation of the transplanted cells into the surrounding striatum of the host brain (Fig. 5b). In contrast, there is little innervation into the host cortex. 


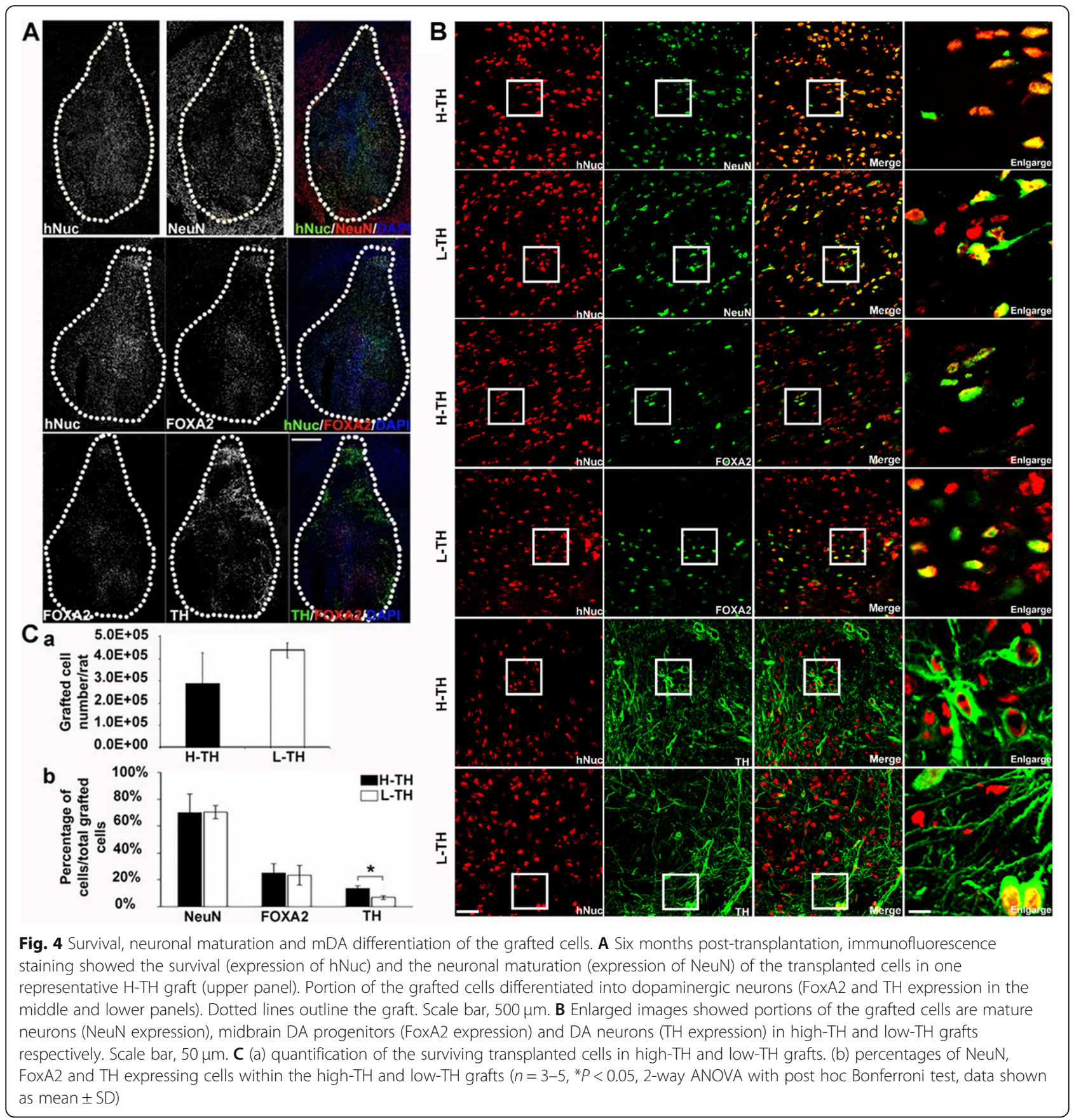

These results indicate the authentic A9-like mDA identity of the differentiated $\mathrm{TH}^{+}$cells.

Correlation between quantitative imaging, $\mathrm{TH}^{+}$count and functional efficacy of the high-TH and low-TH grafts

Imaging, $\mathrm{TH}^{+}$cell yield and behavioural tests are currently the main indices used to predict the therapeutic effect of transplanted cells in PD. Thus, we analysed the correlation between these three indices after transplantation. Rotational behaviour induced by amphetamine administration largely corroborated the $\left[{ }^{18} \mathrm{~F}\right] \mathrm{FBCTT}$ uptake data. One month post-transplantation, neither $\left[{ }^{18} \mathrm{~F}\right]$ FBCTT uptake nor behaviour was able to differentiate the low-TH cell-transplanted cohort $(3.8 \pm 0.4 \%$ $\left[{ }^{18} \mathrm{~F}\right]$ FBCTT uptake and $95.0 \pm 18.7 \%$ of rotations relative to pre-transplant) and high-TH cell-transplanted cohort $\left(5.6 \pm 4.6 \%\left[{ }^{18} \mathrm{~F}\right] \mathrm{FBCTT}\right.$ uptake and $93.2 \pm 38.0 \%$ of rotations relative to pre-transplant). By 3 months, however, low-TH grafted animals showed a small $8.1 \pm 1.2 \%$ increase in $\left[{ }^{18} \mathrm{~F}\right] \mathrm{FBCTT}$ binding but no behavioural recovery $(71.7 \pm 20.7 \%$ of rotations relative to pre-transplant), whereas high-TH grafted animals showed significant 


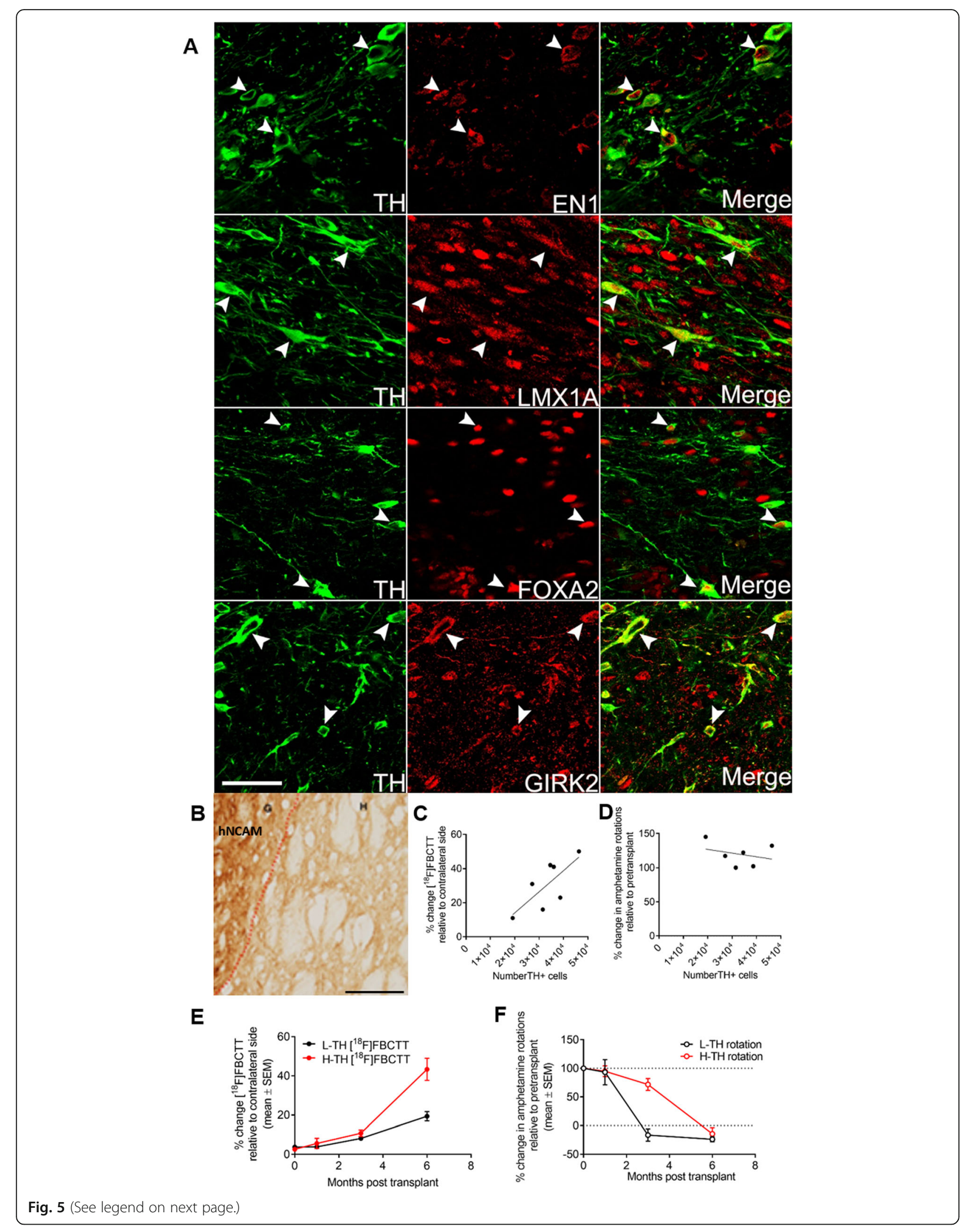


(See figure on previous page.)

Fig. 5 Authentic mDA identity and functional efficacy of the grafted $\mathrm{TH}^{+}$cells and correlations between $\left[{ }^{18} \mathrm{~F}\right] \mathrm{FBCTT}$ imaging, TH count and behavioural recovery in mDA cell-transplanted PD rats. a Immunofluorescence staining for TH (green) and coexpression (red) with EN1 (b), LMX1A (e), FOXA2 (h) and GIRK2 (k). Scale bar, $50 \mu \mathrm{m}$. b IHC-DAB staining using hNCAM antibody revealed the innervation of the transplanted cells from the graft $(\mathrm{G})$ into the surrounding host striatum $(\mathrm{H})$. Scale bar, $100 \mu \mathrm{m}$. c A positive linear correlation between $\left[^{18} \mathrm{~F}\right] \mathrm{FBCTT}$ binding (expressed as $\%$ of the contralateral uptake) and the number of $\mathrm{TH}^{+}$cells per graft at 6 months post-transplantation. $\mathbf{d}$ No correlation between the amphetamineinduced rotation (expressed as \% of pretransplant) and the number of $\mathrm{TH}^{+}$cells per graft at 6 months post-transplantation. e The change in $\left[{ }^{18} \mathrm{~F}\right] \mathrm{FBCTT}$ binding (expressed as \% of the contralateral uptake) in high-TH versus low-TH grafts at 1, 3 and 6 months post-transplantation. f The change in the number of rotations after amphetamine injection longitudinally in high-TH versus low-TH grafts at 1, 3 and

6 months post-transplantation

behavioural improvement $(-16.3 \pm 18.6 \%$ of rotations relative to pre-transplant; Fig. 5c) with only modest $(10.7 \pm 2.9 \%)$ increases in $\left[{ }^{18} \mathrm{~F}\right] \mathrm{FBCTT}$ binding. At 6 months post-transplantation, both low- $\mathrm{TH}$ and high-TH grafted animals showed complete behavioural recovery $(-14.2 \pm 21.2 \%$ and $-23.9 \pm 7.5 \%$ of rotations relative to pre-transplant respectively). Nevertheless, the increases in $\left[{ }^{18} \mathrm{~F}\right] \mathrm{FBCTT}$ binding showed significantly the different uptake between low-TH grafts $(19.4 \pm 4.7 \%)$ and highTH grafts $(43.3 \pm 9.8 \%)\left({ }^{*} P<0.05\right)$. These data indicate that both high-TH and low- TH transplanted cells are able to reverse the behavioural deficit but with different efficacies. Overall, no correlation was observed between behaviour and $\mathrm{TH}^{+}$cell number whereas at six months post-transplantation, a positive linear correlation between the percentage of $\mathrm{TH}^{+}$cells and $\left[{ }^{18} \mathrm{~F}\right] \mathrm{FBCTT}$ binding $\left(R^{2}=0.69\right)$ (Fig. $\left.5 \mathrm{~d}\right)$ was evident. Taken together, these results indicate that $\left[{ }^{18} \mathrm{~F}\right] \mathrm{FBCTT}$ imaging is able to quantify the maturation to $\mathrm{TH}^{+}$cells whilst behavioural tests can be saturated by small changes in $\mathrm{TH}^{+}$cell number.

\section{Discussion}

In vivo maturation of cell transplants into $\mathrm{TH}^{+}$dopaminergic cells is a key indicator for PD cell therapy efficacy and much work has been done to improve the chances of cell maturation prior to implantation. Once clinical trials begin, careful monitoring of cell transplant maturation, efficacy and safety after grafting will be paramount. In the current study, we have used neuroimaging and rotational behaviour to longitudinally assess the maturation and efficacy of grafts of immature hESC$\mathrm{mDA}$ aggregates in vivo after transplantation in a rat model of PD. Rotational behaviour induced by amphetamine is often used to measure the therapeutic efficacy of transplanted cells in preclinical models of PD. However, despite amphetamine-induced rotation being widely accepted as an indicator of the extent of motor function impairment based on TH neuronal loss in substantia nigra, how the reduction of amphetamineinduced rotation relates to pre-synaptic recovery is still poorly understood. Previous studies have shown that low-dose 6-OHDA does not affect amphetamineinduced rotation [26]. A negative hyperbolic, but not linear, correlation was found between amphetamineinduced rotation and loss of DA pre-synaptic function with an overt behavioural abnormality emerging when DAT levels decline below $20 \%$ of normal. Similarly, our data indicates that a small increase in DAT can lead to significant recovery of rotational behaviour. This implies a limitation in predictive value for the rodent behavioural test with respect to the quality of the transplanted cells in PD and underscores the value of neuroimaging in the pre-clinical assessment of cell therapy. Neuroimaging provides a wide range of measures that are useful for the assessment of cell transplants including quantification of cell survival, dopaminergic function in vivo and the contribution of non-dopaminergic cells [20, 27]. In the current study, imaging clearly showed that hESCmDAs can safely and successfully restore presynaptic function and dopamine release in the denervated striatum within 6 months but also reliably assess graft maturation/differentiation in vivo. Histology revealed that whilst all grafts survived equally, they matured to produce neurons with different levels of TH in vivo. Many factors affect graft survival and maturation in vivo including host immune response, biochemistry and site of implantation and imaging can provide useful information to help mitigate these risks.

Clinically, both SPECT imaging with $\left[{ }^{123} \mathrm{I}\right]$ FPCIT $\left(\operatorname{DaTscan}^{\mathrm{n}}{ }^{\mathrm{N}}\right)$ and PET imaging with $\left[{ }^{18} \mathrm{~F}\right] \mathrm{FP}-\beta$-CIT have received the greatest attention in recent years for $\mathrm{PD}$ monitoring and assessment of disease progression and initially the wealth of clinical experience offered an ideal scenario for direct translational comparison with the preclinical imaging presented in this work [19, 28, 29]. However, for the current study, the radiosynthesis of the $\left[{ }^{18} \mathrm{~F}\right] \mathrm{FP}-\beta$-CIT yielded particularly poor results (both radiochemical purity and radioactivity yields), and whilst there have been detailed accounts on the optimization of the manufacturing process for $\left[{ }^{18} \mathrm{~F}\right] \mathrm{FP}-\beta$-CIT [30], our manufacture was further hampered by limited access to viable starting materials. Instead, $\left[{ }^{18} \mathrm{~F}\right] \mathrm{FBCTT}$ was chosen as the DAT PET radiotracer for the current study. $\left[{ }^{18} \mathrm{~F}\right] \mathrm{FBCTT}$ is a closely related tropane-derivative and could be routinely prepared in good radiochemistry yields (19-27\% non-decay corrected yield). Additionally, $\left[{ }^{18} \mathrm{~F}\right] \mathrm{FBCTT}$ has previously been demonstrated to have a 
high affinity for DAT and high selectivity over both norepinephrine and serotonin transporters, DAT $>\mathrm{NET}>>-$ SERT [31, 32].

In the current study, DAT imaging with $\left[{ }^{18} \mathrm{~F}\right] \mathrm{FBCTT}$ robustly correlated to $\mathrm{TH}$ differentiation whereas imaging with $\left[{ }^{18} \mathrm{~F}\right]$ fallypride and rotational behaviour did not. $\left[{ }^{18} \mathrm{~F}\right]$ fallypride, like raclopride, has been used to measure functional dopamine release after transplant and showed that the grafts in the current study functionally released dopamine 6 months after transplant but was unable to differentiate between the high-TH and low-TH grafts. $\left[{ }^{18} \mathrm{~F}\right]$ fallypride has been shown to be a less sensitive measure of striatal dopamine release than $\left[{ }^{11} \mathrm{C}\right]$ raclopride but was used in the current study for logistical reasons where microPET/CT scanning was performed at a site remote from the manufacturing facility and because it allows measurement of $D_{2} / D_{3}$ ligand binding in the striatal and extra-striatal regions. However, $\left[{ }^{11} \mathrm{C}\right]$ raclopride has been shown to provide a more sensitive measure of striatal dopamine release after amphetamine challenge [33, 34], and this may have been more successful in differentiating the high-TH and lowTH grafts. Historically, the majority of clinical studies on foetal tissue grafts have used $\left[{ }^{11} \mathrm{C}\right]$ raclopride and $\left[{ }^{18}\right.$ F]FDOPA imaging to assess graft efficacy $[35,36]$. $\left[{ }^{18} \mathrm{~F}\right]$ FDOPA provides a measure of dopamine biosynthesis and was used for long-term assessment as postmortem studies have shown that some grafted dopamine neurons express progressively lower levels of DAT and $\mathrm{TH}$ decades after transplant, suggesting that the disease process can directly impact the transplanted tissue [17]. However, DAT imaging may be more useful than $\left[{ }^{18} \mathrm{~F}\right] \mathrm{DOPA}$ in the early stages after transplantation. Imaging of DAT provides a reliable early measure of $\mathrm{mDA}$ cell maturation in vivo as DAT is strongly expressed on mature A9-type mDAs [37-44]. Furthermore, during early mDA maturation, interpretation of $\left[{ }^{18} \mathrm{~F}\right] \mathrm{DOPA} \mathrm{im}-$ ages may be complicated by areas of inflammation and/ or on-going dopamine replacement therapies [45-48], whereas DAT imaging is unaffected by these issues.

\section{Conclusions}

Early assessment of cell fate will be important in the clinical assessment of stem cell-derived therapies. This study provides further evidence for the value of in vivo functional imaging for the development of cell therapies and highlights the utility of DAT imaging for the determination of early post-transplant cell maturation and differentiation providing an in vivo measure for cell transplant optimization.

\section{Abbreviations}

\% ID/g: Injected dose/gram; 6-OHDA: 6-Hydroxydopamine; ABC: Avidin biotin complex; ASC: Ascorbic acid; BDNF: Brain-derived neurotrophic factor; BSA: Bovine serum albumin; ChIR: ChIR99021; CIRC: Clinical Imaging Research
Centre; DA: Dopaminergic; DAB: 3,30-Diaminobenzidine; DAT: Dopamine transporter; DOPA: 3,4-Dihydroxyphenylalanine; DPX: Dibutylphthalate Polystyrene Xylene; FBCTT: (1R,2S,3S,5S)-8-Azabicyclo[3.2.1]octane-2-carboxylic acid, 8-(4-fluoro-2-butyn-1-yl)-3-(4-methylphenyl)-methyl ester; FDG: 2-Deoxy2-[ ${ }^{18}$ F]fluoro-D-glucose; FDOPA: 6-Fluoro-L-DOPA; FEP2I: (E)-N-(3-iodoprop-2enyl)-2 $\beta$-carbofluoroethoxy-3 3 -(4'-methyl-phenyl) nortropane;

FGF8: Fibroblast growth factor 8 ; FLT: $\left[{ }^{18} \mathrm{~F}\right]$ fluoro-L-thymidine;

FOXA2: Forkhead box protein A2; FP- $\beta$-CIT: N-3-fluoropropyl-2 $\beta$ carbomethoxy-3 $\beta$-(4-iodophenyl) nortropane; GAPDH: Glyceraldehyde 3phosphate dehydrogenase; GDNF: Glial-derived neurotrophic factor; GIRK2: G protein-activated inward rectifier potassium channel 2; hESCs: Human embryonic stem cells; hESC-DAs: Human embryonic stem cell-derived midbrain dopaminergic neurons; hNUC: Human nucleus antigen; H-TH: Hightyrosine hydroxylase; IC: Immunocytochemistry; IHC: Immunohistochemistry; LDN: LDN193189; L-TH: Low-tyrosine hydroxylase; MBCTT: (1R,2S,3S,5S)-8-

Azabicyclo[3.2.1] octane-2-carboxylic acid, 3-(4-methylphenyl)-8-[4[(methylsulfonyl)oxy]-2-butyn-1-yl]-methyl ester; mDAs: Midbrain

dopaminergic neurons; NEUN: Neuronal nuclei antigen; NET: Norepinephrine transporter; PBS: Phosphate-buffered saline; PD: Parkinsons's disease; PET: Positron emission tomography; PFA: Paraformaldehyde;

PUR: Purmorphamine; ROI: Region of interest; RTP: Room temperature and pressure; SB: SB431542; Shh: ShhC24ll; SERT: Serotonin transporter; SPEC

T: Single-photon computed tomography; TGF $\beta$ : Transforming growth factor beta; TH: Tyrosine hydroxylase

\section{Acknowledgements}

The authors gratefully acknowledge the cyclotron - radiochemistry team at the Clinical Imaging Research Centre (CIRC) for the provision of $\left[{ }^{18} \mathrm{~F}\right]$ fluoride.

\section{Authors' contributions}

Oh, Steve K.W.; Liao, Mei-Chih; and Lin, Youshan Melissa were responsible for the preparation and characterisation of hESC cells for transplantation. Robins, Edward G.; Khanapur, Shivashankar; Jiang, Lingfan; Yong, Fui Fong; Soh, Vanessa; Deng, Xiaozhou; Haslop, Anna; Tan, Peng Wen; and Sadasivam, Pragalath were responsible for the PET radiopharmaceutical manufacturing for pre-clinical imaging. Goggi, Julian L.; Boominathan, Ramasamy; Hartimath, Siddesh V.; and Cheng, Peter were responsible for the animal husbandry and in vivo microPET/CT and MRI imaging experiments. Zeng, Li; Qiu, Lifeng; Zeng, Xiaoxia; Lee, Jolene W.L.; and Zhang Zhiwei were responsible for the preparation of the 6OHDA animal model and IHC characterisation experiments. Robins, Edward G.; Goggi, Julian L.; Oh, Steve K.W.; Zeng, Li; Luthra, Sajinder K.; and Shingleton, William D. were responsible for the conception of the study and organisation of the experimental design and coordination. Robins, Edward G. and Goggi, Julian L. were responsible for the writing of the manuscript. Robins, Edward G.; Goggi, Julian L.; Qiu, Lifeng; Oh, Steve K.W.; Zeng, Li; Tan, Eng King; and Shingleton, William D. were responsible for the critical review of all experimental data and review and revision of the final manuscript. The authors read and approved the final manuscript.

\section{Funding}

This work was supported by funding under a Master Research Agreement between the Agency for Science Technology and Research (A*STAR), Singapore, and GE Healthcare Life Sciences (BMRC 152187 0011/ IAF $311014 \mathrm{~K}$ ).

Availability of data and materials

The datasets used and/or analysed during the current study are available from the corresponding author on reasonable request.

\section{Ethics approval and consent to participate}

Animal procedures were carried out in accordance with the Institutional Animal Care and Use Committee Singapore under IACUC 151089.

\section{Consent for publication}

Not applicable.

\section{Competing interests}

At the time of this study, W.D.S and S.K.L. were employees of GE Healthcare Life Sciences (UK). The other authors indicated no potential conflicts of interest. 


\section{Author details}

${ }^{1}$ Singapore Bioimaging Consortium, A*STAR, 11 Biopolis Way, \#01-02 HELIOS, Singapore 138667, Singapore. ${ }^{2}$ Neural Stem Cell Research Lab, Research Department, National Neuroscience Institute, 11 Jalan Tan Tock Seng, Singapore 308433 , Singapore. ${ }^{3}$ Bioprocessing Technology Institute, A*STAR, 20 Biopolis Way, \#06-01 Centros, Singapore 138668, Singapore. ${ }^{4}$ Research Department, National Neuroscience Institute, SGH Campus, Singapore 169856, Singapore. ${ }^{5}$ Department of Neurology, National Neuroscience Institute, SGH Campus, Singapore 169856, Singapore. ${ }^{6}$ Neuroscience \& Behavioural Disorders Program, DUKE-NUS Graduate Medical School, Singapore 169857, Singapore. ${ }^{7}$ GE Healthcare Life Sciences, White Lion Rd., Little Chalfont, Amersham HP7 9LL, UK. ${ }^{8}$ Lee Kong Chian School of Medicine, Novena Campus, 11 Mandalay Road, Singapore 308232, Singapore. ${ }^{9}$ Clinical Imaging Research Centre, Yong Loo Lin School of Medicine, National University of Singapore, Singapore 117599, Singapore.

\section{Received: 28 January 2020 Revised: 30 June 2020} Accepted: 31 July 2020 Published online: 08 August 2020

\section{References}

1. Ali F, Stott SR, Barker RA. Stem cells and the treatment of Parkinson's disease. Exp Neurol. 2014;260:3-11.

2. Winkler C, Kirik D, Bjorklund A, Cenci MA. L-DOPA-induced dyskinesia in the intrastriatal 6-hydroxydopamine model of Parkinson's disease: relation to motor and cellular parameters of nigrostriatal function. Neurobiol Dis. 2002; 10(2):165-86.

3. Couto MI, Monteiro A, Oliveira A, Lunet N, Massano J. Depression and anxiety following deep brain stimulation in Parkinson's disease: systematic review and meta-analysis. Acta Med Portuguesa. 2014;27(3):372-82.

4. Politis M, Piccini P. Brain imaging after neural transplantation. Prog Brain Res. 2010;184:193-203.

5. Kefalopoulou Z, Politis M, Piccini P, Mencacci N, Bhatia K, Jahanshahi M, et al. Long-term clinical outcome of fetal cell transplantation for Parkinson disease: two case reports. JAMA Neurol. 2014;71(1):83-7.

6. Grealish S, Jonsson ME, Li M, Kirik D, Bjorklund A, Thompson LH. The A9 dopamine neuron component in grafts of ventral mesencephalon is an important determinant for recovery of motor function in a rat model of Parkinson's disease. Brain. 2010;133(Pt 2):482-95.

7. Schultzberg M, Dunnett SB, Bjorklund A, Stenevi U, Hokfelt T, Dockray GJ, et al. Dopamine and cholecystokinin immunoreactive neurons in mesencephalic grafts reinnervating the neostriatum: evidence for selective growth regulation. Neuroscience. 1984;12(1):17-32.

8. Haque NS, LeBlanc CJ, Isacson O. Differential dissection of the rat E16 ventral mesencephalon and survival and reinnervation of the 6-OHDAlesioned striatum by a subset of aldehyde dehydrogenase-positive TH neurons. Cell Transplant. 1997;6(3):239-48.

9. Bjorklund LM, Isacson O. Regulation of dopamine cell type and transmitter function in fetal and stem cell transplantation for Parkinson's disease. Prog Brain Res. 2002;138:411-20.

10. Bjorklund LM, Sanchez-Pernaute R, Chung S, Andersson T, Chen IY, McNaught KS, et al. Embryonic stem cells develop into functional dopaminergic neurons after transplantation in a Parkinson rat model. Proc Natl Acad Sci U S A. 2002;99(4):2344-9.

11. Grealish S, Diguet E, Kirkeby A, Mattsson B, Heuer A, Bramoulle Y, et al. Human ESC-derived dopamine neurons show similar preclinical efficacy and potency to fetal neurons when grafted in a rat model of Parkinson's disease. Cell Stem Cell. 2014;15(5):653-65.

12. Kikuchi T, Morizane A, Doi D, Onoe H, Hayashi T, Kawasaki T, et al. Survival of human induced pluripotent stem cell-derived midbrain dopaminergic neurons in the brain of a primate model of Parkinson's disease. J Park Dis. 2011;1(4):395-412.

13. Hayashi T, Wakao S, Kitada M, Ose T, Watabe H, Kuroda Y, et al. Autologous mesenchymal stem cell-derived dopaminergic neurons function in parkinsonian macaques. J Clin Invest. 2013;123(1):272-84

14. Kikuchi T, Morizane A, Doi D, Magotani H, Onoe H, Hayashi T, et al. Human iPS cell-derived dopaminergic neurons function in a primate Parkinson's disease model. Nature. 2017:548(7669):592-6.

15. Qiu L, Liao MC, Chen AK, Wei S, Xie S, Reuveny S, et al. Immature midbrain dopaminergic neurons derived from floor-plate method improve cell transplantation therapy efficacy for Parkinson's disease. Stem Cells Transl Med. 2017;6(9):1803-14.
16. Dobrossy MD, Braun F, Klein S, Garcia J, Langen KJ, Weber WA, et al. [18F]desmethoxyfallypride as a novel PET radiotracer for quantitative in vivo dopamine D2/D3 receptor imaging in rat models of neurodegenerative diseases. Nucl Med Biol. 2012;39(7):1077-80.

17. Kraemmer J, Kovacs GG, Perju-Dumbrava L, Pirker S, Traub-Weidinger T, Pirker W. Correlation of striatal dopamine transporter imaging with post mortem substantia nigra cell counts. Mov Disord. 2014;29(14):1767-73.

18. Sharma S, Moon CS, Khogali A, Haidous A, Chabenne A, Ojo C, et al. Biomarkers in Parkinson's disease (recent update). Neurochem Int. 2013; 63(3):201-29.

19. Brooks DJ. Molecular imaging of dopamine transporters. Ageing Res Rev. 2016;30:114-21.

20. Pagano G, Niccolini F, Politis M. Imaging in Parkinson's disease. Clin Med. 2016;16(4):371-5.

21. Hargus G, Cui YF, Dihne M, Bernreuther C, Schachner M. In vitro generation of three-dimensional substrate-adherent embryonic stem cell-derived neural aggregates for application in animal models of neurological disorders. Curr Protoc Stem Cell Biol. 2012; Chapter 2:Unit 2D 11.

22. Kirkeby A, Grealish S, Wolf DA, Nelander J, Wood J, Lundblad M, et al. Generation of regionally specified neural progenitors and functional neurons from human embryonic stem cells under defined conditions. Cell Rep. 2012;1(6):703-14.

23. Qiu L, Lim YM, Chen AK, Reuveny S, Oh SK, Tan EK, et al. Microcarrierexpanded neural progenitor cells can survive, differentiate, and innervate host neurons better when transplanted as aggregates. Cell Transplant. 2016; 25(7):1343-57.

24. West MJ. New stereological methods for counting neurons. Neurobiol Aging. 1993;14(4):275-85.

25. West MJ. Stereological methods for estimating the total number of neurons and synapses: issues of precision and bias. Trends Neurosci. 1999;22(2):51-61.

26. Inaji M, Okauchi T, Ando K, Maeda J, Nagai Y, Yoshizaki T, et al. Correlation between quantitative imaging and behavior in unilaterally 6-OHDA-lesioned rats. Brain Res. 2005;1064(1-2):136-45.

27. Politis M. Neuroimaging in Parkinson disease: from research setting to clinical practice. Nat Rev Neurol. 2014;10(12):708-22.

28. Brooks DJ. The role of structural and functional imaging in parkinsonian states with a description of PET technology. Semin Neurol. 2008;28(4):435-45.

29. Brooks DJ. Technology insight: imaging neurodegeneration in Parkinson's disease. Nat Clin Pract Neurol. 2008;4(5):267-77.

30. Lee SJ, Oh SJ, Moon WY, Choi MS, Kim JS, Chi DY, et al. New automated synthesis of [18F]FP-CIT with base amount control affording high and stable radiochemical yield: a 1.5-year production report. Nucl Med Biol. 2011;38(4): 593-7.

31. Riss PJ, Debus F, Hummerich R, Schmidt U, Schloss P, Lueddens $H$, et al. Ex vivo and in vivo evaluation of [18F]PR04.MZ in rodents: a selective dopamine transporter imaging agent. ChemMedChem. 2009;4(9):1480-7.

32. Riss PJ, Roesch F. Efficient microwave-assisted direct radiosynthesis of [(18)F]PR04.MZ and [(18)F]LBT999: selective dopamine transporter ligands for quantitative molecular imaging by means of PET. Bioorg Med Chem. 2009;17(22):7630-4.

33. Kegeles LS, Slifstein M, Xu X, Urban N, Thompson JL, Moadel T, et al. Striatal and extrastriatal dopamine $D_{2} / D_{3}$ receptors in schizophrenia evaluated with $\left[{ }^{18} \mathrm{~F}\right]$ fallypride positron emission tomography. Biol Psychiatry. 2010;68(7): 634-41.

34. Slifstein M, Kegeles LS, Xu X, Thompson JL, Urban N, Castrillon J, et al. Striatal and extrastriatal dopamine release measured with PET and $\left[{ }^{18} \mathrm{~F}\right]$ fallypride. Synapse. 2010;64(5):350-62.

35. Hauser RA, Freeman TB, Snow BJ, Nauert M, Gauger L, Kordower JH, et al. Long-term evaluation of bilateral fetal nigral transplantation in Parkinson disease. Arch Neurol. 1999;56(2):179-87.

36. Kordower JH, Freeman TB, Snow BJ, Vingerhoets FJ, Mufson EJ, Sanberg PR, et al. Neuropathological evidence of graft survival and striatal reinnervation after the transplantation of fetal mesencephalic tissue in a patient with Parkinson's disease. N Engl J Med. 1995;332(17):1118-24.

37. Fu Y, Yuan Y, Halliday G, Rusznak Z, Watson C, Paxinos G. A cytoarchitectonic and chemoarchitectonic analysis of the dopamine cell groups in the substantia nigra, ventral tegmental area, and retrorubral field in the mouse. Brain Struct Funct. 2012;217(2):591-612.

38. Shimada S, Kitayama S, Walther D, Uhl G. Dopamine transporter mRNA: dense expression in ventral midbrain neurons. Brain Res Mol Brain Res. 1992;13(4):359-62. 
39. Cerruti C, Walther DM, Kuhar MJ, Uhl GR. Dopamine transporter mRNA expression is intense in rat midbrain neurons and modest outside midbrain. Brain Res Mol Brain Res. 1993;18(1-2):181-6.

40. Augood SJ, Westmore K, McKenna PJ, Emson PC. Co-expression of dopamine transporter mRNA and tyrosine hydroxylase mRNA in ventral mesencephalic neurones. Brain Res Mol Brain Res. 1993;20(4):328-34.

41. Bannon MJ, Poosch MS, Xia Y, Goebel DJ, Cassin B, Kapatos G. Dopamine transporter mRNA content in human substantia nigra decreases precipitously with age. Proc Natl Acad Sci U S A. 1992;89(15):7095-9.

42. Hurd YL, Pristupa ZB, Herman MM, Niznik HB, Kleinman JE. The dopamine transporter and dopamine D2 receptor messenger RNAs are differentially expressed in limbic- and motor-related subpopulations of human mesencephalic neurons. Neuroscience. 1994;63(2):357-62.

43. Harrington KA, Augood SJ, Kingsbury AE, Foster OJ, Emson PC. Dopamine transporter (Dat) and synaptic vesicle amine transporter (VMAT2) gene expression in the substantia nigra of control and Parkinson's disease. Brain Res Mol Brain Res. 1996;36(1):157-62.

44. Uhl GR, Walther D, Mash D, Faucheux B, Javoy-Agid F. Dopamine transporter messenger RNA in Parkinson's disease and control substantia nigra neurons. Ann Neurol. 1994;35(4):494-8.

45. Karavaeva E, Harris RJ, Leu K, Shabihkhani M, Yong WH, Pope WB, et al. Relationship between $\left.{ }^{[18} \mathrm{F}\right]$ FDOPA PET uptake, apparent diffusion coefficient $(A D C)$, and proliferation rate in recurrent malignant gliomas. Mol Imaging Biol. 2015;17(3):434-42.

46. Sala Q, Metellus P, Taieb D, Kaphan E, Figarella-Branger D, Guedj E. 18FDOPA, a clinically available PET tracer to study brain inflammation? Clin Nucl Med. 2014;39(4):e283-5.

47. Kumakura Y, Cumming P. PET studies of cerebral levodopa metabolism: a review of clinical findings and modeling approaches. Neuroscientist. 2009; 15(6):635-50.

48. Walker MD, Dinelle K, Kornelsen R, McCormick S, Mah C, Holden JE, et al. Invivo measurement of LDOPA uptake, dopamine reserve and turnover in the rat brain using $\left[{ }^{18}\right.$ F]FDOPA PET. J Cereb Blood Flow Metab. 2013;33(1):5966.

\section{Publisher's Note}

Springer Nature remains neutral with regard to jurisdictional claims in published maps and institutional affiliations.

Ready to submit your research? Choose BMC and benefit from:

- fast, convenient online submission

- thorough peer review by experienced researchers in your field

- rapid publication on acceptance

- support for research data, including large and complex data types

- gold Open Access which fosters wider collaboration and increased citations

- maximum visibility for your research: over $100 \mathrm{M}$ website views per year

At $\mathrm{BMC}$, research is always in progress.

Learn more biomedcentral.com/submissions 